\title{
Diagnostic Significance of Urinary Growth Hormone Measurements in Children with Growth Failure: Correlation between Serum and Urine Growth Hormone ${ }^{1}$
}

\author{
CHRISTINE H. ALBINI, JUAN SOTOS, BARRY SHERMAN, ANN JOHANSON, ABBIE CELNIKER, \\ NANCY HOPWOOD, TERESA QUATTRIN, BARBARA J. MILLS, AND \\ MARGARET H. MACGILLIVRAY
}

Department of Pediatrics, School of Medicine at State University of New York at Buffalo, New York 14222 [C.II.A., T.Q., B.J.M., M.H.M.]; Department of Pediatrics, School of Medicine at Ohio State University, Columbus, Ohio 43205 [J.S.]; Genentech, Inc., San Francisco, California 94080 [B.S., A.J., A.C.]: and Department of Pediatrics, School of Medicine, University of Michigan, Ann Arbor, Michigan 48109 [N.II.]

\begin{abstract}
Twelve-h overnight urine and serum samples obtained simultaneously at 20 -min intervals were assayed for growth hormone (GH). Ninety-one children, 5 to $16 \mathrm{y}$ (Tanner stage 1 to 3 ) participated; group 1 were healthy children, group 2 were children with organic GH deficiency, and group 3 had idiopathic growth failure and normal GH stimulation tests. Serum pool GH concentrations in group 1 were similar to those in group 3 (3.3 00.3 versus $3.4 \pm 0.2 \mu \mathrm{g} / \mathrm{L})$; group 2 had significantly lower $\mathrm{GH}$ concentrations (1.6 $\pm 0.2 \mu \mathrm{g} / \mathrm{L})$. Plasma IGF-I levels were significantly greater in groups $1(14.2 \pm 2.6 \mathrm{nmol} / \mathrm{L}, p<$ $0.001)$ than in groups 2 and $3(2.6 \pm 0.5$ and $5.5 \pm 0.7$ $\mathrm{nmol} / \mathrm{L}$, respectively). Urinary GH (mean \pm SEM) standardized for body weight $(\mu \mathrm{g} / \mathrm{kg})$ in group $1(0.31 \pm 0.02)$ was significantly greater than in group $2(0.14 \pm 0.01)$ and group $3(0.20 \pm 0.01)$. However, when expressed as $\mu \mathrm{g} / \mathrm{mol}$ creatinine, the output of $\mathrm{GH}$ was similar in group $1(4.0 \pm 0.3)$ and group $3(3.4 \pm 0.3)$; both groups had significantly greater output compared to group $2(1.3 \pm$ $0.2)$. Urinary IGF-I $(\mathrm{nmol} / \mathrm{kg})$ in group $1(0.22 \pm 0.02)$ was significantly greater than in group $2(0.12 \pm 0.01)$ or group $3(0.07 \pm 0.01)$. Urinary GH correlated with serum pool GH concentration $(r=0.64, p<0.001)$. Although urinary GH output reflects endogenous GH secretion, the overlap between groups 1 and 3 precludes using urinary GH measurements as a diagnostic test for GH deficiency in children with idiopathic growth failure. (Pediatr Res 29: 619-622, 1991)
\end{abstract}

\section{Abbreviations}

GH, growth hormone
$\mathrm{Cr}$, creatinine

stimuli. Diminished spontaneous GH secretion has been proposed as an explanation for the growth failure observed in these children (1-3). Attempts to detect low spontaneous GH secretion have utilized serial blood sampling or constant blood withdrawal over 12- to 24-h periods. Both of these methods are labor intensive and inappropriate for use in infants and young children. Recently, Rose et al. (4), questioned the diagnostic usefulness of serial plasma measurements because the mean 24-h plasma $\mathrm{GH}$ concentrations in children with idiopathic short stature were not significantly different from normal controls when the study populations were matched for stage of puberty. Furthermore, more than $50 \%$ of children with classical GH deficiency had normal spontaneous GH secretion.

We have recently reported that measurements of urinary $\mathrm{GH}$ and IGF-I provide quantitative information about the amount of hormone excreted in infants and children with normal and abnormal growth (5-7). We have also shown that urinary $G H$ and IGF-I correlated positively, that urinary IGF-I is GH dependent, and that both urinary peptides are authentic based on HPLC characterization.

We hypothesized that measurement of urinary GH and IGF-I might be a useful and noninvasive method of detecting $\mathrm{GH}$ deficiency in pathologically short children who had normal GH responses to standard provocative tests. To test this hypothesis, we simultaneously measured urinary GH output and pooled plasma $\mathrm{GH}$ concentrations derived from overnight serial blood sampling at 20 -min intervals in children with either normal stature, organic hypopituitarism, or idiopathic growth failure. The data derived from plasma and urine $\mathrm{GH}$ measurements were analyzed statistically to learn whether urinary $\mathrm{GH}$ output reflected mean plasma $\mathrm{GH}$ concentration and whether subtle deficiencies of $\mathrm{GH}$ can be identified in children with idiopathic growth failure. In this study, IGF-I was also quantitated in urine and plasma.

\section{MATERIALS AND METHODS}

Recent clinical studies have suggested that pathologically short children may have subtle deficiencies of GH that escape diagnosis because they exhibit normal GH responses to pharmacologic

Received September 24, 1990; acceptcd January 31, 1991

Correspondence and reprint requests: Christine Albini, M.D., Children's Hospital of Buffalo, Division of Endocrinology, 219 Bryant Street, Buffalo, NY 14222.

Supported in part by the Ralph Hochstetter Medical Research Fund in Honor of Dr. Henry C. and Bertha H. Buswell.

'Presented in part as a poster at the Endocrine Society, Seattle, WA, June $21-$ 24. 1989. Ninety-one children participated in this study after their par-
ents gave written informed consent. Age, sex, and pubertal status of the study participants are shown in Table 1. The subjects were divided into the following three groups. Group 1 consisted of 32 healthy children (ages 7-15 y) growing between the 5th and 95th percentile for height and weight who served as controls. Group 2 consisted of 13 children with organic GH deficiency (ages 5$13 \mathrm{y})$ due to prior cranial irradiation for brain tumors or leukemia. All children were GH deficient based on a peak $\mathrm{GH}$ of less 
than $10 \mu \mathrm{g} / \mathrm{L}$ after two or more standard stimulation tests (insulin-induced hypoglycemia, L-arginine infusion or L-dopa). Group 3 consisted of 46 children (ages 5-17 y) with idiopathic growth failure whose heights were greater than $-2 \mathrm{SD}$ and who had growth rates less than $5 \mathrm{~cm} / \mathrm{y}$. Their peak $\mathrm{GH}$ responses were $>10 \mu \mathrm{g} / \mathrm{L}$ to one of two or more GH-provocative tests.

All patients were admitted to the Special Studies unit the afternoon of the test procedure. Spontaneous overnight $\mathrm{GH}$ secretion was assessed by obtaining blood samples every $20 \mathrm{~min}$ for a $12-\mathrm{h}$ period ( $2000-0800 \mathrm{~h}$ ). Simultaneously, overnight urine collections $(2000-0800 \mathrm{~h})$ were obtained in a plastic container and kept at $4^{\circ} \mathrm{C}$ throughout the collection period.

A 50-mL aliquot of urine was centrifuged to remove particulate matter and subsequently dialyzed, lyophilized, and reconstituted in $1 \mathrm{~mL} 0.04 \mathrm{M}$ phosphate buffer, ph 7.4 , containing $0.5 \%$ purified serum albumin (albuminar 25; Armour Pharmaceutical Co., Kankakee, IL), and $0.9 \%$ sodium chloride as previously described (5-7).

$\mathrm{GH}$ in serum and urine concentrates were measured in duplicate by a standard double antibody RIA method using polyclonal GH antibody and GH standards obtained from the National Hormone and Pituitary Program $(8,9)$. The intraassay and interassay coefficients of variation for $\mathrm{GH}$ were 2.1 and $4 \%$, respectively.

IGF-I in plasma and urine concentrates were quantitated in duplicate using RIA kits purchased from Nichols Institute Diagnostics (San Juan Capistrano, CA). The intra- and interassay coefficients of variation were 5.7 and $8.6 \%$, respectively.

The data were analyzed using analysis of variance with post hoc comparisons based on the Student-Newman-Keuls test.

\section{RESULTS}

There was no significant difference observed in the serum pool $\mathrm{GH}$ values obtained from healthy children $(3.3 \pm 0.2 \mu \mathrm{g} / \mathrm{L})$ and those from children with idiopathic growth failure $(3.4 \pm 0.2$ $\mu \mathrm{g} / \mathrm{L}$ ) (Table 2). Patients with organic $\mathrm{GH}$ deficiency had significantly lower serum pool $\mathrm{GH}$ values $(1.6 \pm 0.2)$ compared to children in groups 1 and $3(p<0.05)$. A scattergram of the individual serum pool $\mathrm{GH}$ values for the participants in the three groups is shown in Figure 1.

Urinary GH output was standardized for body weight $(\mu \mathrm{g} / \mathrm{kg} /$ $12 \mathrm{~h})$ and grams of $\mathrm{Cr}(\mu \mathrm{g} / \mathrm{mol} \mathrm{Cr})$. The mean $( \pm \mathrm{SEM})$ for each of the study groups is shown in Table 2 . Based on body weight, urinary $\mathrm{GH}$ output was significantly greater in the healthy controls $(0.31 \pm 0.02 \mu \mathrm{g} / \mathrm{kg})$ than in children with organic $\mathrm{GH}$ deficiency $(0.14 \pm 0.01 \mu \mathrm{g} / \mathrm{kg})$ or children with idiopathic growth

Table 1. Clinical data of study participants

\begin{tabular}{|c|c|c|c|c|c|}
\hline \multirow[b]{2}{*}{ Groups } & \multirow[b]{2}{*}{$n$} & \multirow{2}{*}{$\begin{array}{c}\text { Tanner } \\
\text { stage }\end{array}$} & \multirow[b]{2}{*}{ Age $(y)$} & \multicolumn{2}{|c|}{ SD Units } \\
\hline & & & & Height & Weight \\
\hline 1 & 32 & $1-3$ & $10.6 \pm 0.3$ & $1.0 \pm 0.2$ & $0.8 \pm 0.2$ \\
\hline 2 & 13 & $1-3$ & $8.1 \pm 0.7$ & $-0.9 \pm 0.4$ & $-0.1 \pm 0.3$ \\
\hline 3 & 46 & $1-3$ & $11.6 \pm 0.5$ & $-2.4 \pm 0.1$ & $-1.2 \pm 0.1$ \\
\hline
\end{tabular}

Table 2. Urinary and serum $G H$ in healthy controls, $G H$-deficient children, and subjects with idiopathic growth failure

\begin{tabular}{cccc}
\hline & \multicolumn{2}{c}{ Urine GH } & Serum GH \\
\cline { 2 - 3 } Groups & $(\mu \mathrm{g} / \mathrm{kg})$ & $(\mu \mathrm{g} / \mathrm{mol} \mathrm{Cr})$ & $(\mu \mathrm{g} / \mathrm{L})$ \\
\hline 1 & $0.31 \pm 0.02$ & $4.0 \pm 0.3$ & $3.3 \pm 0.3$ \\
2 & $0.14 \pm 0.01$ & $1.3 \pm 0.2$ & $1.6 \pm 0.2$ \\
3 & $0.20 \pm 0.01$ & $3.4 \pm 0.3$ & $3.4 \pm 0.02$ \\
& $F=17.0$ & $F=14.3$ & $F=7.2$ \\
& $p<0.01$ & $p<0.01$ & $p<0.01$ \\
SNK & 1 vs 2,3 & 2 vs 1,3 & 2 vs 1,3 \\
\hline
\end{tabular}

\footnotetext{
* SNK, Student-Newman-Keuls test.
}

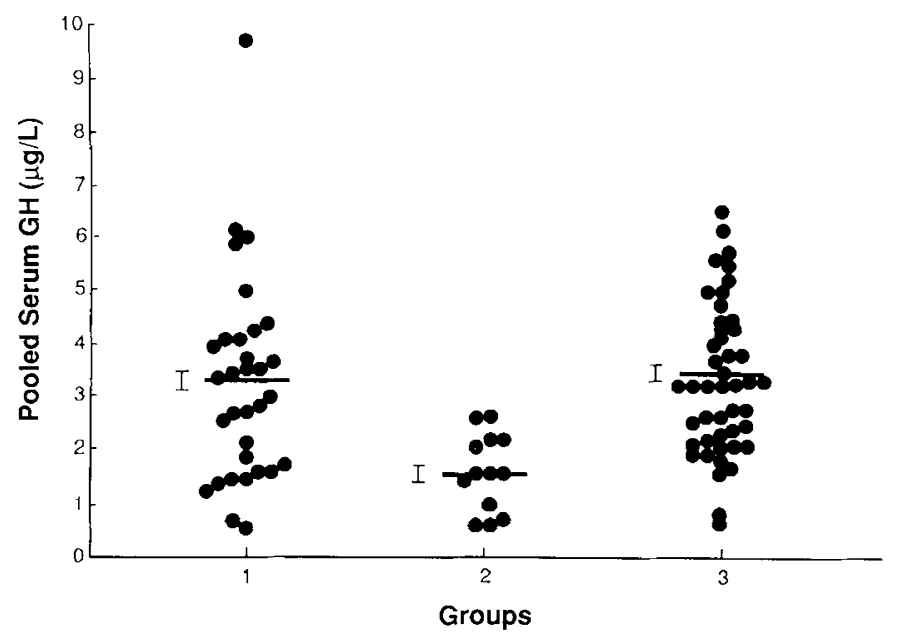

Fig. 1. Pooled serum GH concentrations in healthy controls (group 1), GH-deficient subjects (group 2), and children with idiopathic growth failure (group 3). The horizontal and vertical lines indicate the mean \pm SEM.

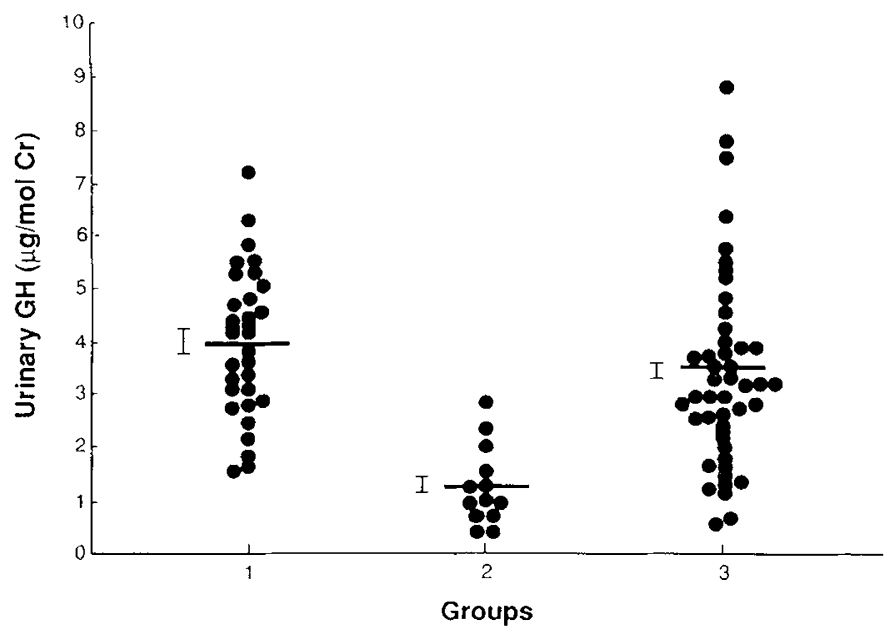

Fig. 2. Mean $( \pm$ SEM) urinary GH values in the three study groups.

failure $(0.20 \pm 0.01 \mu \mathrm{g} / \mathrm{kg}, p<0.05)$. There was no significant difference in children of group 2 versus group 3.

When the data were standardized according to $\mathrm{Cr}$ excretion, children in group $1(4.0 \pm 0.3 \mu \mathrm{g} / \mathrm{mol} \mathrm{Cr})$ had significantly higher urinary $\mathrm{GH}$ output compared to subjects in group $2(1.3 \pm 0.2$ $\mu \mathrm{g} / \mathrm{mol} \mathrm{Cr})$. However, the output of urinary $\mathrm{GH}$ in group $3(3.4$ $\pm 0.3 \mu \mathrm{g} / \mathrm{mol} \mathrm{Cr}$ ) was no longer significantly different from group 1. Figure 2 illustrates the degree of overlap observed among the groups.

Urinary GH output correlated positively with the serum pool GH concentrations ( $r=0.64, p<0.001)$ (Fig. 3). The strongest correlation between urinary GH output and serum pool levels was observed in group $1(r=0.73, p<0.0)$.

Plasma IGF-I levels and urinary IGF-I output expressed as $\mathrm{nmol} / \mathrm{kg}$ and $\mathrm{nmol} / \mathrm{mol}$ of $\mathrm{Cr}$ for the three study groups are shown in Table 3. Plasma IGF-I levels in group $1(14.2 \pm 2.5$ $\mathrm{nmol} / \mathrm{L}$ ) were significantly greater compared to those of children with organic $\mathrm{GH}$ deficiency $(2.6 \pm 0.5 \mathrm{nmol} / \mathrm{L})$ or children with idiopathic growth failure $(5.5 \pm 0.7 \mathrm{nmol} / \mathrm{L}, p<0.05)$.

Urinary IGF-I output was significantly higher in group $1(0.22$ $\pm 0.02 \mathrm{nmol} / \mathrm{kg} ; 3.0 \pm 0.3 \mathrm{nmol} / \mathrm{mol} \mathrm{Cr}$ ) compared to group 2 $(0.12 \pm 0.01 \mathrm{nmol} / \mathrm{kg} ; 1.1 \pm 0.3 \mathrm{nmol} / \mathrm{mol} \mathrm{Cr})$ or group $3(0.07$ $\pm 0.01 \mathrm{nmol} / \mathrm{kg} ; 1.2 \pm 0.10 \mathrm{nmol} / \mathrm{mol} \mathrm{Cr}$ ). The low renal output of IGF-I in groups 2 and 3 was not significantly different when expressed in terms of body weight or $\mathrm{Cr}$ excretion. Figure 4 


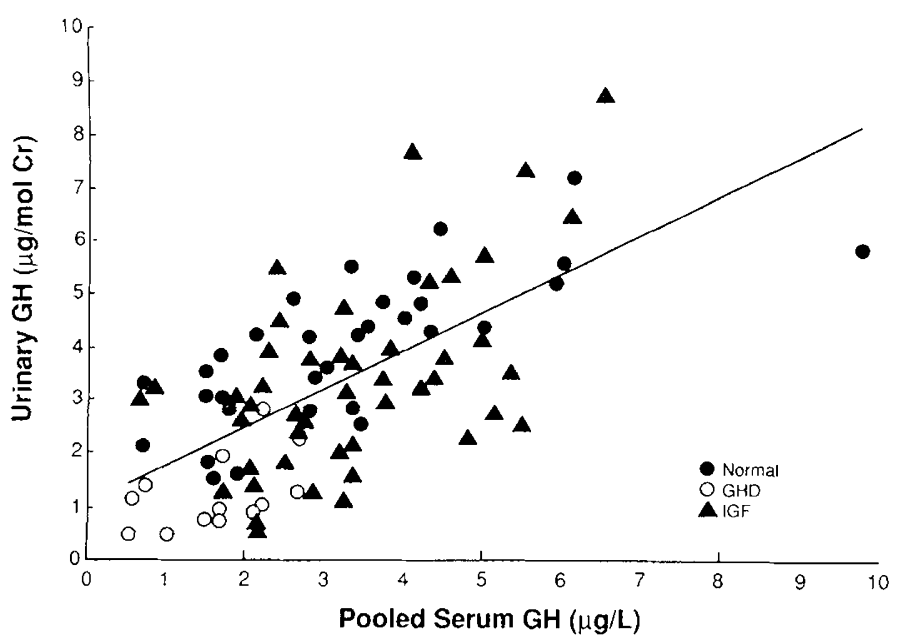

Fig. 3. Correlation between urinary $\mathrm{GH}$ excretion and pooled serum $\mathrm{GH}$ concentrations $(r=0.64 ; p<0.001)$.

Table 3. Urinary and plasma IGF-I in healthy controls, GH-deficient children, and subjects with idiopathic growth failure

\begin{tabular}{cccc}
\hline & \multicolumn{2}{c}{ Urine IGF-I } & \\
\cline { 2 - 3 } Groups & $(\mathrm{nmol} / \mathrm{kg})$ & $(\mathrm{nmol} / \mathrm{mol} \mathrm{Cr})$ & $\begin{array}{c}\text { Plasma IGF-I } \\
(\mathrm{nmol} / \mathrm{L})\end{array}$ \\
\hline 1 & $0.22 \pm 0.02$ & $3.0 \pm 0.3$ & $14.2 \pm 2.5$ \\
2 & $0.12 \pm 0.01$ & $1.1 \pm 0.3$ & $2.6 \pm 0.5$ \\
3 & $0.07 \pm 0.01$ & $1.2 \pm 0.1$ & $5.5 \pm 0.7$ \\
& $F=25.5$ & $F=23.0$ & $F=16.5$ \\
& $p<0.01$ & $p<0.01$ & $p<0.01$ \\
SNK* & 1 vs 2,3 & 1 vs 2,3 & 1 vs 2,3 \\
\hline
\end{tabular}

* SNK, Student-Newman-Keuls test.

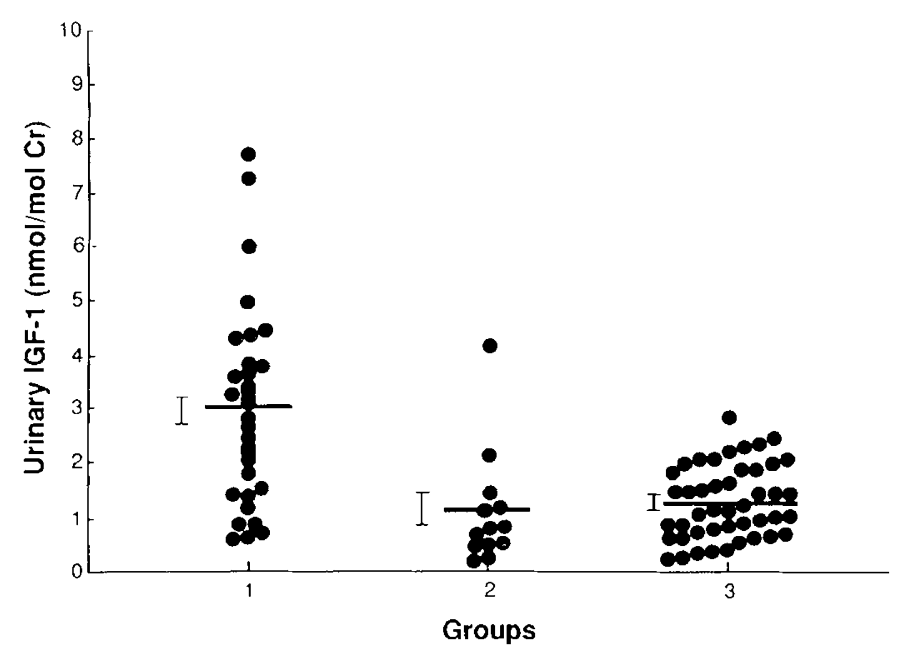

Fig. 4. Output of urinary IGF-I in the three groups. Bars indicate the mean \pm SEM.

illustrates the individual urinary IGF-I measurements in the three study groups.

A moderately positive correlation was observed between plasma and urinary IGF-I $(r=0.41, p<0.01)$.

\section{DISCUSSION}

Our study confirms that the output of $\mathrm{GH}$ in timed urine collections accurately reflects serum pool GH concentrations derived from serial blood samples obtained simultaneously at 20 -min intervals. For the 91 participants, the highly positive correlation between serum and urinary GH values $(r=0.64$ in all subjects and 0.71 in control groups) compares favorably with a similar correlation reported by Sukegawa et al. (10) $(r=0.81)$ in 24-h studies of 25 short children and four hypopituitary patients. A positive correlation between serum and urinary $\mathrm{GH}$ values in our patients was observed when the data were standardized for body weight $(\mu \mathrm{g} / \mathrm{kg})$ or urinary $\mathrm{Cr}(\mu \mathrm{g} / \mathrm{mol} \mathrm{Cr})$. This observation strengthens the conclusions reached by our previous study, which took advantage of the noninvasive and semiquantitative features of urinary $\mathrm{GH}$ measurements to compare $\mathrm{GH}$ production throughout infancy and childhood $(5,7)$. Normal renal function was a requisite for measuring urinary $\mathrm{GH}$ output, inasmuch as the presence of glomerular or tubular disease results in spurious estimates of urinary $\mathrm{GH}$ excretion $(11,12)$.

Among our three study populations, the overlap observed in the serum pool GH concentrations and the urinary GH measurements was of such magnitude that a difference in the $\mathrm{GH}$ status of pathologically short children was not clearly delineated from that of control subjects. A similar problem with the overnight serial blood sampling protocol has been reported by other investigators who questioned the diagnostic validity of this test in children with idiopathic short stature (4). Although our pathologically short children in this and an earlier study had significantly lower urinary $\mathrm{GH}$ output than controls when the data were expressed as $\mu \mathrm{g} / \mathrm{kg}$ of body weight, the difference was not statistically significant when the data were expressed as $\mu \mathrm{g}$ per mol of $\mathrm{Cr}(5)$. Because $\mathrm{Cr}$ excretion reflects muscle mass, lower output of urinary $\mathrm{Cr}$ in short or hypopituitary children tends to falsely elevate urinary GH excretion (13-15). The hypopituitary children in our present study were less severely affected compared to those described previously, hence their relatively higher outputs of urinary GH and greater degree of overlap with control children (2). Lastly, our data confirm the findings reported by others concerning the wide range and unexpectedly low values of mean serum GH concentrations as well as urinary GH outputs in normal children (16-18). This characteristic of healthy children is likely to make it extremely difficult to develop a sensitive, accurate test of subtle GH deficiency.

The labor-intensive RIA used to measure urinary GH output in our study yields data that is comparable to the results obtained with more sensitive ELISA (Hashida males 6.1-37 ng/g Cr, females $4.7-25 \mathrm{ng} / \mathrm{g} \mathrm{Cr})(19-21)$. Both methods indicate that urinary $\mathrm{GH}$ output is highest in infants and that growing children excrete more $\mathrm{GH}$ than adults.

Urinary IGF-I measurements, in contrast to the urinary GH results, have much less overlap among our three study groups. Although opinions differ as to the proportion of IGF-I bound to IGF-I binding proteins, their presence did not appreciably change the results of assays performed on unextracted versus extracted urine concentrations (unpublished observations). The significantly lower IGF-I output in our pathologically short children cannot be readily explained. This group did not appear to be nutritionally deficient by physical examination or $Z$ scores for weight.

The positive correlation between the outputs of urinary $\mathrm{GH}$ and IGF-I in this study confirms the findings in an earlier investigation, which concluded that the observed relationship between these peptides in urine provides strong evidence in support of the somatomedin hypothesis.

Although urinary GH measurements alone may not sufficiently discriminate which child with idiopathic short stature will benefit from GH therapy, it is possible that additional follow-up of these children will provide information about the diagnostic value of measuring both urinary GH and IGF-I in this population. Children with classical $\mathrm{GH}$ deficiency can be identified using these screening tests. Also, measurements of these peptides in urine have yielded information about the relative merits of different $\mathrm{GH}$ doses and treatment schedules and may aid in monitoring compliance in children undergoing $\mathrm{GH}$ treatment (22). 
Acknowledgments. The authors thank Deborah Wachowicz for her help with manuscript preparation. We also thank our laboratory technicians Irene Johnson, Cindy Malek, and Lisa Phillips.

\section{REFERENCES}

1. Spiliotis BE、 August GP, Hung W, Sonis W, Mendelson W, Bercu BB 1984 Growth hormone neurosecretory dysfunction. JAMA 251:2223-2230

2. Zadik Z, Chalew SA, Raiti S, Kowarski AA 1985 Do short children secrete insufficient growth hormone? Pediatrics 76:355-360

3. Bercu BB, Shulman D, Root AW, Spiliotis BE 1986 Growth hormone (GH) provocative testing frequently does not reflect endogenous $\mathrm{GH}$ secretion. J Clin Endocrinol Metab 63:709-716

4. Rose SR, Ross JL, Uriarte M, Barnes KM, Cassorla FG, Cutler GB 1988 The advantage of measuring stimulated as compared with spontaneous growth hormone levels in the diagnosis of growth hormone deficiency. J Clin Endocrinol Metab 329:201-207

5. Albini, C, Quattrin T, Vandlen RL, MacGillivray MH 1988 Quantitation of urinary growth hormone in children with normal and abnormal growth. Pediatr Res 23:89-92

6. Quattrin T, Albini C, Vandlen RL, MacGillivray MH 1988 Quantitation of urinary somatomedin-C (SM C/IGF-I) in children with normal and abnormal growth. J Clin Endocrinol Metab 65:1168-1171

7. Quattrin T, Albini C, Cara JF, Vandlen RL, Mills BJ, MacGillivray MH 1988 Quantitation of urinary somatomedin-C and growth hormone in preterm and fullterm infants and normal children. J Clin Endocrinol Metab 66:792797

8. Schalch DS, Parker ML 1964 A sensitive double antibody immunoassay for human growth hormone in plasma. Nature 203:1141-1145

9. Greenwood FG. Hunter W, Glover JS 1963 The preparation of I-131 labeled human growth hormone of high specific radioactivity. Biochem J 89:1 [4123

10. Sukegawa I, Hizuka N, Takano K, Asakawa K, Horikawa R, Hashida S, Ishikawa E, Mohri Z, Murakami Y, Shizume K 1988 Urinary growth hormone $(\mathrm{GH})$ measurements are useful in evaluating endogenous $\mathrm{GH}$ secretion. J Clin Endocrinol Metab 66:1119-1123

11. Kato Y, Hattori N. Murakami Y, Hashida S, Ishikawa E, Mohri Z, Murakam
Y 1987 Clinical use of ultra sensitive enzyme immunoassay of urine growth hormone in patients with pituitary disorders. Endocrine Society, Indianapolis, IN, Junc 10-12, p 78

12. Hattori N, Kato Y, Murakami Y, Hashida S, Ishikawa E, Mohri Z, Imura $H$ 1988 Urinary growth hormone levels measured by ultrasensitive enzyme immunoassay in patients with renal insufficiency. $\mathbf{J}$ Clin Endocrinol Metab 66:727-732

13. Forbes $\mathrm{G}$, Bruining $\mathrm{G} 1976$ Urinary creatinine excretion and lean body mass. Am J Clin Nutr 29:1359-1366

14. Ballard F. Burgoyne J, Thomas F, Penfold JL 1983 Growth hormone induced changes in myofibrillar protein breakdown in hypopituitary children. Clin Sci $64: 315-320$

15. Richter I. Heine W, Plath C. Mix M, Wutzke KD, Toroe J $198715 \mathrm{~N}$ tracer techniques for the differential diagnosis of dwarfism and prediction of growth hormone action in children. $J$ Clin Endocrinol Metab 65:74-77

16. Girard J, Erb T, Pampalone A. Eberle AN, Baumann JB 1987 Growth hormone in urine: development of an ultrasensitive assay applicable to plasma and urine. Hormone Res 28:71-80

17. Lanes R 1989 Diagnostic limitations of spontaneous growth hormone measurements in normally growing prepubertal children. Am J Dis Child 143:1284-1286

18. Celniker A Fehskens E, Fletcher B Chen A 1988 A Sensitive ELISA for the quantitation of $\mathrm{hGH}$ in urine. Genentech National Cooperative Growth Symposium III, Palm Desert, CA, October 27-30, pp 9-10

19. Hashida S, Ishikawa E, Nakajawa K, Ohtaki S, Ichioka T, Nakajima K 1985 Demonstration of human growth hormone in normal urine by a highly specific and sensitive sandwich enzyme immunoassay. Anal Lett 18:16231634

20. Hashida S, Ishikawa E, Nokajawa R, Ohtaki S, Shingenaga H, Hayakawa K, Mohri Z, Murakami Y, Ichioka T, Nakajima K 1986 Level of human growth hormone in urine determined by a kidney specific and sensitive sandwich enzyme immunoassay. Anal Lett 19:625-638

21. Ishikawa E. Hashida S, Kato Y, Imura H 1987 Sensitive enzyme immunoassay of human growth hormone for clinical applications: a review. J Clin Lab Anal 1:238-242

22. Albini CH, Quattrin T, Mills BJ, Sherman B, Johanson A 1990 Effects of growth hormone $(\mathrm{GH})$ treatment schedule on urinary $\mathrm{GH}$ and insulin-like growth factor I output during thrice weekly vs. daily administration. Endocrine Society, Atlanta. GA, June 20-23, p 312 